
ICIP WORKING PAPERS:
2012/1

The analysis of the framing

processes of the Basque peace movement: The way Lokarri and Gesto por la Paz changed society

Egoitz Gago Anton

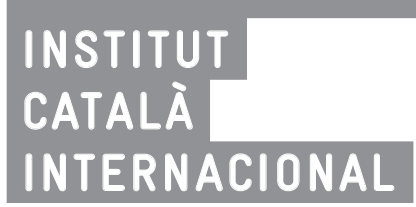




\section{The analysis of the framing processes of the Basque peace movement: The way Lokarri and Gesto por la Paz changed society}

Egoitz Gago Anton

Doctor in Peace Studies, University of Bradford, United Kingdom.

Institut Català Internacional per la Pau Barcelona, January 2012 


\section{Institut Català Internacional per la Pau}

Gran Via de les Corts Catalanes 658, baixos · o8010 Barcelona

T. +34935544270 | F. +34935544280

recerca.icip@gencat.cat|http://www.icip.cat

\section{Editors}

Javier Alcalde and Rafael Grasa

\section{Editorial Board}

Pablo Aguiar, Laia Balcells, Alfons Barceló, Gema Collantes-Celador, Caterina Garcia, Abel Escribà, Tica Font, Antoni Pigrau, Xavier Pons, Alejandro Pozo, Mònica Sabata, Jaume Saura, Josep Maria Terricabras and Léonie Van Tongeren

\section{Graphic Design}

Fundació Tam-Tam

\section{Typesseting and printing}

Ātona, S.L. / gama, sl

\section{ISSN}

2013-5793 (online edition)

2013-5785 (paper edition)

\section{DL}

B-17.175-2012 


\section{THE AUTHOR}

Egoitz Gago holds a political science degree by the University of the Basque Country and a doctoral degree in peace studies by the Department of Peace Studies at the University of Bradford, United Kingdom. This paper is based on his $\mathrm{PhD}$ research thesis, which took him to have extensive knowledge about the Basque peace movement against political violence. Currently he is involved in the study of social collectives affected by violence, specially the way collective action against violence is developed in different environments, like Europe and Latin America.

\section{ABSTRACT}

During more than 20 years organisations like Gesto por la Paz and Lokarri had been trying to change the social approach to violence, instilling values of peace and dialogue. This working paper defends the idea that the work of these two organisations is key to understand the end of ETA violence and the lack of support that political violence has in the Basque Country. It develops the Basque peace frame generated by this movement and explains how this frame is present in the different levels of Basque society, changing the way political collective identities are negotiated in the Basque Country. Ultimately, their effort is to propose another way of doing politics, one where nationalism and violence are not intrinsically united, escaping from the polarization and confrontation that were in place during the 80s-90s.

Keywords: Basque Peace Movement, Peace Mobilisation, Basque Conflict, Social Movement Impact. 


\section{RESUM}

Durant més de 20 anys, organitzacions com Gesto por la Paz i Lokarri han estat tractant de canviar l'enfocament social de la violència, inculcant valors de pau i diàleg. Aquest document de treball defensa la idea que el treball d'aquestes dues organitzacions és clau per entendre el final de la violència d'ETA i la falta de suport que té la violència políticaal País Basc. El text desenvolupa el marc de la pau basca generat per les organitzacions pacifistes i explica com aquest marc està present en els diferent nivells de la societat basca, canviant la forma en què les identitats col-lectives polítiques es negocien al País Basc. En darrer terme proposa una altra forma de fer política, on el nacionalisme i el la violència no estiguin intrínsecament units, escapant de la polarització i la confrontació del anys 80 i 90.

Paraules clau: Moviment basc per la pau, mobilització per la pau, conflicte basc, impacte dels moviments socials.

\section{RESUMEN}

Durante más de 20 años, organizaciones como Gesto por la Paz y Lokarri han estado tratando de cambiar el enfoque social de la violencia, inculcando valores de paz y diálogo. Este documento de trabajo defiende la idea de que el trabajo de estas dos organizaciones es clave para entender el final de la violencia de ETA y la falta de apoyo que tiene la violencia política en el País Vasco. El texto desarrolla el marco de la paz vasca generado por este movimiento y explica cómo este marco está presente en los diferentes niveles de la sociedad vasca, cambiando la forma en que se negocian las identidades colectivas políticas en el País Vasco. En última instancia, propone otra forma de hacer política, donde el nacionalismo y el la violencia no estén intrínsecamente unidos, escapando de la polarización y la confrontación de los años 80 y 90.

Palabras clave: Movimiento vasco por la paz, movilización por la paz, conflicto vasco, impacto de los movimientos sociales. 


\section{CONTENTS}

1. INTRODUCTION

2. THE PEACE MOVEMENT ORGANISATIONS: GESTO POR LA PAZ AND LOKARRI

3. THE BASQUE PEACE ACTIONFRAME AND THE IDENTITY PROCESSES OF THE BASQUE PEACE MOVEMENT

THE BASQUE PEACE ACTION FRAME

BASQUE PEACE ACTION FRAME PROCESSES, TASKS AND FEATURES

BACKGROUND OF THE BASQUE PEACE ACTION FRAME AND COLLECTIVE IDENTITY PROCESSES IN THE BASQUE PEACE MOVEMENT

4. FRAME EFFECTS OF THE BASQUE PEACE MOVEMENT. HOW DO THEY CHANGE SOCIETY?

5. CONCLUSIONS

6. BIBLIOGRAPHY 



\section{INTRODUCTION}

In February 2012, during the moment this article was written, Gesto por la Paz, the Basque peace organization announced its last annual peace march. This marches have been part of the social landscape in the Basque Country for more than 25 years, and it was one of the pillars upon peace mobilisation was constructed. Few months before, the social network for the agreement, Lokarri organised, amongst other international organisations, a day peace conference in San Sebastian. The result of that conference was a text urging ETA to stop any violent act and the opening of a dialogue process between the violent organisation and the Spanish government to solve to so-called Basque conflict. The next day, ETA announced the complete cease of the use of violence.

These two situations are not mutually isolated. They are the consequence of years of peace protest in the Basque Country, of a struggle between political identities (peaceful and violent) that shaped the way Basque society perceives and reacts to political violence. This working paper describes this process, defining the Basque peace movement, its efforts, and the way the society shares its perceptions and ideas. To understand the current political and social situation in the Basque Country it is key to comprehend and explore the social mobilisation against the violence that has been happening since the end of the Franco dictatorship. During that period of political repression, peace identity was alive as a submerged network overshadowed by a public discourse that legitimated violent action against the state. When the new democratic regime was established in 1975 , that submerged peace identity found new spaces to be expressed. The political opportunity structure opened up to allow the expression of rejection of violence and a process of contestation of the public space that was monopolized with a violent expression of national politics. During years, the expression of Basque nationalism was identified with a confrontational way of making politics and, in the extremes, supported by the use of political violence. What the peace movement does in the Basque Coun- 
try is to propose a new ways of doing politics, stepping away from the polarisation and dichotomies of the past (nationalist-violent), trying to transform the different perceptions about the conflict in society.

This paper identifies the Basque peace movement ${ }^{1}$ as the myriad of organisations and groups that appeared during the early 80 s to protest against the political violence that emanated from the political conflict generated by the national struggle. However, it is possible to simplify this set of organisations into two: Gesto por la Paz (Gesture for Peace) and Lokarri (Bond). These are the two most successful peace organisations and both represent most of the demands that identifies the peace movement from others. Moreover, Gesto por la Paz, was born to coordinate the different local groups that appeared to protest against political violence. These two organisations have been extremely successful articulating demands and mobilizing resources and they mostly monopolize the nonviolent protest in the Basque Country.

Gesto por la Paz and Lokarri were able to create a comprehensive peace action frame (the Basque peace action frame), which was the main tool to counter the strong public presence of contentious methods of protest. This frame presents a diagnosis of the presence of violence in the Basque Country, identifying that violence as the main problem for the presence of peace. Not only the frame makes a diagnosis of the problem but clearly identifies the main actors that cause it, in

1. The Basque Country has different kinds of peace movements. This paper identifies as the "Basque peace movement" the network of organisations that appeared to confront the violence generated from the Basque national conflict. This does not assumed that there are not other peace movements active, like the anti military movement or a more holistic peace movement. For more information about the different categories of peace movements see: Overy, B. (1982) How effective are peace movements?, London, Harvest House. For more information about other kind of peace movements in the Basque Country see: Ajangiz, R. (2002) Politica Militar y Movimientos Sociales: El fin de la conscripcion en Europa, Bilbao, Servicio Editorial de la UPV/EHU., and BARCENA, I., IbARRA, P. \& Zubiaga, M. (1998) Movimientos sociales y democracia en Euskadi. Insumision y ecologismo. IN IBARRA, P. \& TEJERINA, B. (Eds.) Los Movimientos Sociales, transformaciones politicas y cambio cultural. Madrid, Trotta.

2. Lokarri was created in 2006 from another organization called Elkarri (Dialogue). Both organisations shared several points in common. Actually, Lokarri can be understood as a continuation of Elkarri with organizational and procedural changes. In the text, the name Lokarri is mainly used, meaning Lokarri/Elkarri. 
this case the armed group ETA and the security bodies of the Spanish state. It is important to understand that these two organisations do not consider the political debate about nationalism the main problem, but the presence of direct violence. This is a key element in their discourse, as both organisations defend a democratic process to settle the national disputes. The frame not only provides a diagnosis, also a solution to the problem. In this case is to stop all the actors to use violence to promote a scenario of peace. The solution is shared by both organisations, but with a very important difference. Gesto por la Paz advocates for a scenario of absence of violence and let the democratic institutions the role of normalization of social relations. Lokarri, on the other hand, sees the end of violence as the first step to a reconciliation scenario where civil society and political actors converge together. This is the main difference between organisations, as Lokarri promotes a political proposal to resolve the conflict. Finally, the frame offers a set of instructions to achieve that solution. Both organisations encourages social mobilisation as the main pillar to achieve that solution. Gesto por la Paz promotes a more "classical" mobilisation, with marches and symbolic acts, like the Gesto, a silent demonstration of 15 minutes made after any politically motivated killing. Lokarri uses online tools, meetings, and forums to debate and promote its political agenda. This "division of labour" is consequence of the nature of the two organisations, Gesto por la Paz being more "social" in its approach and Lokarri being more "political". This specialization caused that both organisations are extremely efficient in what their do, not having to devote resources into issues that overlapped each other's work. However, this issue does not mean that both organisations did not try methods traditionally reserved for the other. Lokarri called several times for local demonstrations and Gesto por la Paz regularly holds meetings to raise debate about different issues like the situations of violence victims.

This Basque peace action frame and the organisations that enforce it are the result of a complex identity negotiation process that started before democracy arrived in the Basque Country. The peace identity, present widely in Basque society had to struggle against a contentious 
identity that defended the need of violence to enforce national ideas. This identity was hidden due political circumstances, as the perception that violence was needed to overthrow Franco. Finally, with democracy, the peace identity was able to resurface, claiming a more prominent position amongst Basque society.

This paper combines these different factors: peace movement, Basque peace action frame and peace identity negotiation processes, to present the change of Basque perceptions about the conflict and to explain why, now, it is possible to speak about peace in a region where seemed very unlikely to happen. The paper will be divided in four main sections, explaining the nature of the two main peace organisations, Gesto por la Paz and Lokarri, the Basque peace action frame, and how this frame changed the identity negotiation processes inside Basque society, transforming the perceptions of the conflict from an acquiescence of violence to a total rejection of it. For that exercise it explores the effect of the Basque peace action frame in other civil society networks related to the conflict, as the nationalist left and the victims of terrorism. The result is a narrative that explores the effect of peace mobilisation in the Basque Country and gives some ideas and hints about the way we should look at social action in places of conflict.

\section{THE PEACE MOVEMENT \\ ORGANISATIONS: GESTO POR LA PAZ AND LOKARRI.}

In this section both peace organisations will be described, explaining what were the circumstances that lead to their formation and what has been their history so far. Most of the information of this section comes from Maria Jesus Funes work (Funes, 1998a; 1998b), that explains Gesto por la Paz and Lokarri up to 1998, when Lokarri was known as Elkarri.

Gesto por la Paz appeared in 1986 to answer the growing unrest in Basque society about the political violence present. The conflict 
trends were still similar to those that were dominant during the dictatorship. The nationalist left ${ }^{3}$ parties and social organisations defended the need of the "armed struggle" (Funes, 1998a: 55). The change of the political opportunity structure in the early 80 s alongside the consolidation of a nationalist political option in power created the conditions for the appearance of a peace movement. The pacifist identity was present inside Basque society in the form of a submerged network (Melucci, 1989: 60) with a very limited access to a public space of protest. This limitation disappeared with the arrival of democracy, as the perception of violent struggle waned. Since the beginning, Gesto por la Paz understood that the main objective was to reclaim the public space to defend pacifist ideas, as this space was completely taken by the nationalist left with a contentious repertoire of action that justified the existence of violence (Casquette, 2003). On the other hand, Lokarri appeared later, in 1992. Protest networks created around environmental issues (Letamendia, 1994c: 344-377) took the peace mobilisation that Gesto por la Paz created and gave it a new ingredient, a political proposal. The new organisation was called Elkarri (Dialogue), and in 2006 became Lokarri. Elkarri not only presented a frontal opposition against the use of violence, but added guidelines to understand the political future after the end of that violence. That future was based on the negotiation and dialogue between political actors, with a scenario of social and political reconciliation at the end.

The relationship between the two organisations has been complex. At the organisational level, Gesto por la Paz and Lokarri seemed opposite, with different ways of protesting, managing resources, and objectives. However, at the micro level, several members shared membership, being active members of both organisations. Soon, it became clear that each organisation would be in charge of one aspect of the peace social movement, with Gesto por la Paz clearly dominating the social protest, and Lokarri adopting an approach closer to a pressure

3. Nationalist left refers to Izquierda Abertzale in Spanish. This denotes the political actors that defend a left-wing position with a fierce nationalist component. Traditionally, this sector is very close to ETA. 
group than a social movement organisation (De la Peña \& Ibarra, 2004: 85). This division of labour helps to explain the success of the Basque peace action frame as both organisations devoted resources to promote their particular area of interest.

\section{GESTO POR LA PAZ}

Gesto por la Paz was created in 1986 to coordinate the actions of several local peace groups that appeared to contest the use of political violence in the Basque Country. Gesto por la Paz's primary objective is to protest against that political violence and to motivate Basque society against that violence (Funes, 1998a: 39). The importance of Gesto por la Paz for the evolution of the conflict can be measured looking at the difficulty to take that step and become an organisation. The Basque Country was still a place where protesting against violence was seen with extreme polarisation. The visualisation of an organisation that did not support the contentious and violent use of the public sphere made Gesto por la Paz an unwelcomed actor for the nationalist left network that saw a threat in the new organisation. Gesto por la Paz brought a different way of using the public space, using silent mobilisation to promote its ideas ${ }^{4}$. This made Gesto por la Paz a revolutionary actor that shaped the nature of the peace movement and that created an inflexion point in the history of social mobilisation in the Basque Country (Tejerina, 2001: 53).

Gesto por la Paz brought a highly symbolic mobilisation model, not based on numbers, but on images. Key to that principle, the organisation created the Gesto, a silent gathering or still demonstration, that takes place the day after a politically motivated killing and lasts 15 minutes. The Gestos are called automatically, at a place and a time that is pre-fixed ${ }^{5}$. The affluence at the Gestos was scarce at the beginning. This way of mobilisation allowed the organisation to maximize

4. For a complete description of Gesto por la Paz's mobilisation rules: http://www.gesto. org/movilizacion.htm (accessed: 20/02/2012).

5. List of places and times for Gestos: http://www.gesto.org/gestos.htm (accessed: 20/02/2012) 
the resources and impact in society. Gesto por la Paz did not need to call a Gesto every time a killing happened, but made it automatic, easy to access and easy to understand (Funes, 1998b: 505). The objective was to create a clear image in contrast of the violent marches explained before (Funes, 1998a: 41). Paradoxically, Gesto por la Paz choose silence to break the cultural routine of remain silent towards the existence of political violence. More importantly, the Gesto was the first initiative aimed to transform the social perception of the conflict, giving a possibility to the pacifist social sectors to break the dominant framework. As the mobilisation progressed, the Gesto became part of the organisation's main rituals, as be part of one Gesto became the basic point to considered one person member of Gesto por la Paz. Another important symbolic tool generated by Gesto por la Paz was the Lazo Azul (Blue Ribbon). This is a piece of blue cloth in the shape of an 'A' meant to be wear by any person close to the organisation's ethos. The Lazo Azul was created to protest against the kidnappings that were in place in the 9os. With the explosion of success that happened at the end of the 9os, the Lazo Azul was commonly used, not only to protest against political violence, but also to protest against Basque nationalist politics (Anton, 2011: 127). This issue was not well received inside Gesto por la Paz, as they did not reject Basque politics. Actually, Gesto por la Paz's ethos is based on the idea that the conflict could be understood as having two different sides ${ }^{6}$. One side, the political conflict, is legitimate and has to be solved using political tools and institutions. The other, the violent conflict, is the one that needs to be rejected and dismissed (Anton, 2011: 128). This difference is key to understand the relationship between Gesto por la Paz and other social organisations that used its mobilisation repertoire, like victims of terrorism organisations. Gesto por la Paz will be advocating the defence and recognition of victims of terrorism using different actions, as speeches or seminars, but will clash with their political agenda, that includes a total rejection of nationalist politics (Dominguez, 2003). To conclude, it is clear that Gesto por la Paz's history is based on the

6. As explained in Gesto por la Paz's magazine, Bake Hitzak, issue 58. 
transformative efforts of their actions, trying to separate politics and violence. For that purpose, it developed a highly symbolic mobilisation repertoire that aimed to delegitimize the use of violence in the public space and gave a way of express the submerged pacifist ideas that were present in Basque society. The organisation was starting to present a new ways of doing politics in the Basque Country trying to transform the existent violent framework to a more peaceful framework. However, Gesto por la Paz did not have a political proposal that made clear the path to follow after achieving that peaceful framework. Consequence of that void, another organisation appeared: Elkarri, that later will become Lokarri.

\section{LOKARRI}

Lokarri was stablished in March 2006 after a long debating process inside Elkarri, an organisation created in 1992 to promote a peaceful and dialogued conflict resolution in the Basque Country. This paper understands Lokarri as a continuation of Elkarri in terms of ethos and objectives. Elkarri was born 6 years after the appearance of Gesto por la Paz. At its beginning, Elkarri did not identify itself as a pacifist organisation, but an organisation that worked for dialogue and mediation (Funes, 1998a: 47). However, the nature of the new organisation cannot be understood without the presence of Gesto por la Paz and an inherent pacifist identity. Elkarri was born from the social networks created around environmental issues in the province of Gipuzkoa, particularly a social collective known as Lurraldea (Barcena et al., 1995; 1998). The main contribution of Elkarri towards the peace movement was the addition of a political discourse, a code of conduct for political actors that saw dialogue as the main ingredient, instead of confrontation. The two organisations had issues were they clashed, as Elkarri weighed the political outcomes of every action. One clear example is that, opposite to Gesto por la Paz, Elkarri defended that the first step to achieve peace was to established dialogue between confrontational actors. Asking ETA to stop violence was, to Elkarri, a way to give it the initiative for a hypothetical conflict resolution scenario 
(Funes, 1998a: 48). Elkarri had clear that their main objective was not to mobilize people, but to change the approach to politics of the different actors. For that reason, they adopted methods and repertoires closer to pressure groups than social movement organisations, like developing strong links with political parties (De la Peña \& Ibarra, 2004: 85). However, the organisation tried to convince society of their actions. For that goal they developed an active campaign to collect signatures to support some of their actions. These signature collection exercises were so numerous that they become central for the organisation, with a role similar to the Gesto in Gesto por la Paz. To be part of a signature collection activity was (and still is inside Lokarri), as a the moment to become a real member of Elkarri (Anton, 2011: 200).

The main goal achieve by Elkarri is the inclusion of the word 'dialogue' inside everyday political discourse in the Basque Country. The idea that national politics cannot be discussed and only opposed or supported is long gone. This is a similar effect that Gesto por la Paz achieved in social terms, but Elkarri's objective is more measurable through political discourses. The specialization that marked both organisations made this possible, as Elkarri developed political means of impact, through meetings and conferences with the different political actors. This issue allowed the organisation to open channels of communication with almost every political force present in the Basque Country. These channels proved essential to understand the frame diffusion in the future. However, the polarization of national politics did not leave the peace movement alone. The openness of Elkarri, and the allegiance to the nationalist left of some of its members gave the idea to some social sectors the Elkarri was the response to the nationalist left to the peace movement (Funes, 1998a: 47). The relationship between Elkarri and the nationalist left is very complex, as Elkarri is a heterogeneous organisation with a diverse membership. A big part of Elkarri members were active participants in the Gestos that missed the political side of the peace movement. However, the perception of nearness that Elkarri had amongst members of the nationalist left network, made it a suitable organisation to join if the idea of the use of violence was not shared. This issue is widely contested by Lokarri, 
stressing the fact that the organisation does not support any political agenda than dialogue and peaceful conflict resolution?

In 2005, Elkarri perceived that the situation was changing, and launched an internal process of transformation ${ }^{8}$. The level of political violence was decreasing, and the organisation had the perception that new challenges lied ahead. Elkarri was transformed into Lokarri with the main goal of preparing Basque society for a reconciliation scenario. The new organisation is smaller, with less full time members, with new goals, but with a similar strategy: to present a political proposal to implement in a post-violence scenario. To achieve this the organisation built a strategy around the use of online tools, like forums and blogs. This was not well received well amongst Lokarri members, but it gradually was accepted, mostly to ensure the cohesion inside the membership (Anton, 2009). The organisational change brought a leadership change that was seen suspiciously by some membership sectors. This issue has disappeared, especially with the latest successes. Lokarri is the most visible of the peace movement organisations in the current situation, as it is the main conductor of the institutional declarations that made way for the ETA ceasefire in October 2011. This is giving relevance to Lokarri with a momentum than is allowing the organisation to promote its ethos inside the political actors, not only in the Basque Country, but also at the national and international level. The moment of Lokarri is contrast with Gesto por la Paz's, which announced its last call for a annual peace march. However, this is consequence of the main Lokarri's focus, the post-conflict scenario. During the last six years, the organisation has been developing strategies to confront this difficult period, trying to get together the different political forces in play and giving a message of hope to Basque society. However, it is important to acknowledge the work done by Gesto por la Paz. It is because of its actions that now, Basque society is fully aware of its pacifist identity. Metaphorically speaking, it is possible to

7 Lokarri foundational document: http://lokarri.org/index.php/es/acerca-de-lokarri/ publicaciones/documento-constitutivo-de-lokarri (accessed 20/02/2012).

8 This process can be consulted at: http://www.elkarri.org/actualidad/object. php?o=2210 (accessed 20/02/2012) 
say that Gesto por la Paz prepared the soil and planted the seeds, and Lokarri is tending the garden.

\section{THE BASQUE PEACE ACTION FRAME AND THE IDENTITY PROCESSES OF THE BASQUE PEACE MOVEMENT}

An frame is a set of rules, an 'schemata of interpretation' that enable individuals 'to locate, perceive, identify, and label' occurrences within their life space and the world at large (Goffman, 1974: 21). Applied to social movements research, frames become collective action frames, gaining two distinctive features: to be applied to groups of people and to have a clear call for mobilisation. They still perform the interpretive function noted by Goffman, but they are 'intended to mobilize potential adherents and constituents, to garner bystander support, and to demobilize antagonists' (Snow \& Benford, 1988: 198). They are action-oriented sets of beliefs and meanings that inspire and legitimate the activities and campaigns of social movement organisations (Snow \& Benford, 2000: 614), and are the outcomes of negotiating shared meanings (Gamson, 1992: 111). This paper analyses the work of the two Basque peace organisations constructing their action frame and looking at how this action frame has permeated Basque society. For that purpose, it is important to define the Basque peace action frame, the set of rules, values and beliefs that Gesto por la Paz and Lokarri have been defending. The Basque peace action frame is the main tool of this analysis, but it did not appear by chance. It is grounded on the complex collective identity processes that are present inside Basque society. After explaining the Basque peace action frame, these collective identity processes are visited, giving the opportunity to paint a whole picture of how peace social action has been shaped in the Basque Country. 


\section{THE BASQUE PEACE ACTION FRAME}

The frame created and enforced by Gesto por la Paz and Lokarri can be defined as follows:

- The violence exerted by ETA and the Spanish police apparatus is the main source of suffering in the Basque Country. Two important issues arise from this assumption: that the nationalist politics are not necessarily the problem, and that the work of Gesto por la Paz and Lokarri is focused on that specific violent manifestation.

- The only plausible move towards a reasonable conflict resolution scenario is the total end of that violence: ETA should stop and announce its dissolution, and the Spanish government has to respect and enforce the democratic principles of the rule of law and human rights ${ }^{9}$.

- The Basque social network is torn and divided by the violence derived from political goals, specifically nationalistic goals.

- The presence of political violence is the main cause for peace mobilisation in the Basque Country, as society needs spaces to express itself about peace. In this regard, the Basque peace organisations provide these spaces.

- The demands of society and the problems stated before can only be resolved through a process of absence of violence that will lead to a reconciliation scenario between parts of Basque society. This process has to be achieved with the active commitment of the Basque political parties.

These five points are common in the perception of the situation by Gesto por la Paz and Lokarri. However, there are some differences that deserve mention. These differences come from the difference approach to political violence of both organisations. Gesto por la Paz stresses the need of reject violence, whatever the cost. That does not involve starting a process of dialogue with any particular social or political actor, just to raise awareness in society about the problem. On

9 Gesto por la Paz's goals: http://www.gesto.org/fines.htm (accessed 20/02/2012) and Lokarri foundational document, page 4: http://www.lokarri.org/files/es/Constitutivo_ Lokarri.pdf (accessed 20/02/2012) 
the other hand, Lokarri needs social and political actors to share the frame. This provokes tensions between organisations, as they take different stands about controversial issues, like the role of victims of terrorism or the role of ETA in the hypothetical future of the Basque Country.

\section{BASQUE PEACE ACTION FRAME PROCESSES, TASKS AND FEATURES}

It is the role of the Basque peace movement to promote and defend its perception of the conflict. These efforts are defined in social movements literature as core framing tasks, processes and features (Snow et al., 1986). In the case of the Basque peace movement, the core framing tasks will be visited and it will be stressed the most important framing process, the framing transformation process.

There are three main framing tasks: diagnosis, prognosis, and motivation. These tasks define the problem; the culprits and they offer a way to fix it (Snow \& Benford, 2000: 615). The diagnostic task identifies the problem and attribute blame, the prognostic tasks presents a suitable solution, and the motivational task is a 'call for action' (Gerhards \& Rucht, 1992: 230; Hunt et al., 1994: 191; Snow \& Benford, 1988: 199; 2000: 616).

The diagnostic task attributes the problem to the existence of violence, with ETA and the Spanish police apparatus as the main culprits. Both organisations shared the same position about this. However, the difference of approach makes the expression of it slightly different. Gesto por la Paz, as defender of the democratic political institutions, only charge blame on the police institutions if they do something explicitly wrong. Lokarri, on the other hand, tries both parts to acknowledge their role in the conflict, a condition needed for a dialogue conflict resolution. Therefore, is more common in Lokarri's public discourses the presence of demands to the Spanish police forces.

The prognostic task defends the idea of reconciliation and the end of political violence as the main solution for the conflict. Both organisations share this approach, with only minor differences in the way the 
solution has to be implemented. Gesto por la Paz defends the idea that violence has to stop totally before thinking about reconciliation. Lokarri does not share that position, as waiting for ETA to act gives it underserved political power.

Finally, the call for action, the motivational task is where both organisations differ most. Lokarri proposes a scenario where the main action has to be done by political actors, in the form of agreements and debate. The role of society is to encourage that position, normally through signed documents or participation in forums, seminars and meetings. Gesto por la Paz stress the importance of rebellion against the existence of political violence and calls for massive gatherings where numbers and symbols (silence, blue ribbon) are prominent. The message is not for any political actors but for the actors that use political violence to stop.

Apart from the core framing tasks, collective action frames try to connect with other sectors, frames and actors. The mechanisms are called frame alignment processes (Snow et al., 1986). Amongst them, the most important in the Basque peace movement case is the transformation efforts or frame transformation. The work of Gesto por la Paz and Lokarri can be defined as a struggle to change perception about the conflict, to transform the contentious, violent frame that ruled the behaviour towards politics into a new one. The use of the public space done by Gesto por la Paz had the objective to challenge the assumptions about the use of violence. The goal was to send a message that other way of politics was possible. Gesto por la Paz presents a new way of understand collective identities regarding politics, as a perfect example of keying (Goffman, 1974: 43-44). The efforts of changing perceptions define Gesto por la Paz and works as a measurement of success (Goffman, 1974: 45). The feeling inside Gesto por la Paz in the current situation is that the work is done, as society is publicly moving away from political polarization. Lokarri shares the same goal, but its objective is the political actors. The effort is centred on the conciliation of political parties and institutions with the tenements of the frame. Using frame theory, this is a case of transformation of a specific domain (Snow et al., 1986: 474). In this case, the conflict is the 
specific domain. The organisations seldom try to change other political perceptions, nor try to actively oppose other kind of violence. Finally, it is important to repeat the idea that the change proposed by the Basque peace movement is not only of perceptions, but a change of creation of collective identities. This will entail a new way of relationships, a change of rules for autonomous behaviour, defining the other and managing relations with peers (Melucci, 1996: 68-74). This is due the particular processes that were in place to construct political identities in the Basque Country that shaped the way the frame is formulated and contested.

BACKGROUND OF THE BASQUE PEACE ACTION FRAME AND COLLECTIVE IDENTITY PROCESSES IN THE BASQUE PEACE MOVEMENT

The Basque peace movement organizations, Gesto por la Paz and Lokarri, started their history during the mid 1980s. Democracy had just arrived to the Basque Country, and the changes derived from the transition period were becoming evident. The Dictatorship period was characterized by authoritarian repression all over Spain, with the exception of the Basque Country and Catalonia, with a totalitarian approach to the nationalist phenomena (Alvarez-Junco, 1994: 313). Social action in that period was galvanized around counter-dictatorship movements, with the actions of ETA as the clearest manifestation. The different political collective identity processes present in Basque society were private and mostly related to nationalism (Perez-Agote, 2008: 140). From those dynamics, it is possible to say that mobilization during the transition period was monopolized by a particular sector of Basque society: the nationalist left that is sympathetic with ETA actions. (Casquette, 2003: 20). The different networks that capitalized those collective identity processes suffered a mutation with the opening of the political structure, or the transition to democracy. Some of them remained as before, leaving the social mobilization for contentious political demands, but others, mainly small parochial groups, saw an opportunity to make public their demands for peace. These demands were submerged dur- 
ing the dictatorship period, when the public space was monopolized by contentious action against the Spanish regime (Casquette, 2003; 2005). These small groups conformed later what is known as Gesto por la Paz (Funes, 1998a: 39). The appearance of the Gestos created the conditions to generate a new identity process. This process is derived from that new frame of analyzing conflict. Violence is not seen as a useful tool to achieve political goals and has to be rejected.

This had a definitive impact in some social networks that found problems in the transition to democracy. These networks started to include identity consciousness in several campaigns. The best known was the protest against the construction of the Leizaran highway that led to the creation of the Lurraldea collective. This campaign was a success and created the conditions in which some of the groups could make themselves public. They took the action frame that Gesto por la Paz developed, and they added the political proposal as a new variable. The people involved in that process created Elkarri, later known as Lokarri. The main objective of the Basque peace movement since that moment was to transform the different collective identity processes that were present in society concerning politics.

The Basque peace movement is the result of a combination of different processes that were in place long time before it appeared. These processes were social in nature, and they were the creation of new protest spaces, the creation of a perception to address a historical conflict. Using the words of Alberto Melucci, Gesto por la Paz and Lokarri are the visual consequence of a different set of orientations of action, of elements of structure and motivation that were combined in a variable manner (Melucci, 1988: 331). Therefore, to understand the different mechanisms of how the frame operates it is important to understand the different mechanisms of creation of political collective identity that take place in the Basque Country. Traditionally, these collective identities revolved around one issue: the recognition of the Basque Country as a nation. In different levels, the Basque Country always had a relation with the Spanish State based on a mutual agreement. This relationship was not always cordial and violence broke out (Letamendia, 1994a) but always under the basic framework of a political 
agreement. Therefore, the construction of political identity in the Basque Country was equally carried out in the private sphere (friends, families, grassroots communities) and the public sphere (political parties, open social organizations). The political structure was open and recognized. This process existed at two levels: at community level, that is, inside the families and the group of friends, and at social level, that is, towards external actors, like political institutions, schools and work places. These dynamics changed with the Franco dictatorship. During the Franco regime, everything that was Basque or related to Basqueness was banned from the public sphere. Public demonstrations were prohibited, and the use of the Basque language was forbidden. Basque identity was only maintained and nurtured at the communal level, or private level, inside the families and groups of friends (Perez-Agote, 2008). During the dictatorship, there was a struggle between two political identities, one that legitimated the Spanish State and another that did not. The later was the nationalist option, which embraced the disruption of the Spanish State using violence (PerezAgote, 2008: 102). It was during the days of the dictatorship when ETA was created, not as an autonomous entity, but as an armed movement, consequence of the dictatorial repression (Ibarra, 1987). Some authors defend the idea that ETA could be better understood as a social movement with a violent repertoire than as a terrorist group in that time (Wieviorka, 1993: 169). With the arrival of the democratization process, the pacifist identity parted with the indissoluble association of nationalism and violence offering a new option: the pursuit of a nationalistic project had nothing to do with political violence. There is clear the transformative objective of the peace discourse. The rejection of violence was a key element to properly pursue that goal. Gesto por la Paz defends the separation of conflicts, one political, another violent ${ }^{10}$. Lokarri has a well-developed political proposal that is based on the rejection of political violence.

10. See "To split violence and politics: an old and a good idea" by Imanol Zubero. In Gesto por la Paz fundamental issues: http://www.gesto.org/separarviolenciaypolitica.htm (accessed 22/02/2012) and Gesto por la Paz magazine Bake Hitzak No 58 "Separation of Conflicts". 
Political collective identities are a recognized way of perceiving the other in the Basque Country. The Basque national identity is been constructed continuously for centuries and is well established as a defining political feature (Castells, 1998: 30). The national identity, therefore, works as an exclusive construction, thanks to the different processes of radicalization that were underway during the dictatorship (Perez-Agote, 2008: 135). This trend is changing as noted by various authors (Ibarra, 2005; Perez-Agote, 1998) who have detected trends of inclusion in the Basque national identity. This is relevant for this paper explaining the identity position of the nationalist left as this collective still relies in old ways of reproduction of identities. This fact makes the nationalist left less prone to defining themselves with any other political position but nationalist.

Every social movement starts from a field of common relations, a place where new meanings (Melucci, 1989: 58) are constructed. Melucci calls these fields "submerged networks" (Melucci, 1989: 60). These submerged networks function as a "system of exchanges, in which individuals and information circulates" (Melucci, 1989: 60) and they constitute the submerged reality of the movements during and after visible events (Bartholomew \& Mayer, 1992: 145; Melucci, 1988: 338). In the case of the Basque peace movement, its message was a new way of understanding and fighting politics. The processes of political collective identity created around the Basque identity during the dictatorship had a violent component (Perez-Agote, 2008: 101). The Basque peace movement tries to enforce the idea of political identity without that violent component. The main difference between the network during the dictatorship and the movement that appeared in the 1980 s was the arrival of democracy to the Basque Country. Before that, the idea of non-violence existed in Basque society, mainly in private circles. They lacked the social support to be public. During the dictatorship, any political action was meant as a stand for or against the national struggle. Most parts of society supported the idea of political debate without violence, but the meaning and significance of violence was becoming more important for some of the nationalist groups, mainly ETA. During the dictatorship, political action in the 
public sphere was limited to the nationalist left agenda (Casquette, 2003: 20; 2006: 125). This public political action took the form of marches and riots, and was contentious in nature. The social sector that monopolized this kind of protest, the nationalist left, was the closest to the armed struggle and ETA (Muro, 2008: 115).

The impact of that scenario in the processes of creation of a peace collective identity was significant in two ways. Firstly, it created a division between members of the nationalists left and pacifists. More specifically, it created an implicit division between being a nationalist and a pacifist because violence was associated to the former. Secondly, it limited the access of pacifists networks to the public space, hampering the emergence of social movements as access is one of the necessary elements for growth (Casquette, 1998: 81; Diani, 1992: 5; Tarrow, 1998: 71; Tilly, 1978; 1984: 306). Therefore, the Basque peace identity during the dictatorship was characterized by questioning the use of violence as a political instrument and a high level of latency (Bartholomew \& Mayer, 1992: 145; Melucci, 1989: 60; 1996: 115) due to the lack of public space (Funes, 1998a: 90; 1998b: 494). In this scenario two dimensions emerged that were important to understand the generation of a peace collective identity during democracy: national identity and political activism. Both were contentious in the Basque peace movement organizations because they meant identification with the use of violence. It was not a coincidence that Gesto por la Paz defined itself as an apolitical organization with no national discourse. ${ }^{11}$

The main factor that drove the transition from latency to visibility (Melucci, 1988: 338) in the Basque peace movement was the implementation of democracy. This factor translated in an aperture of the political opportunity structure in the form of civil liberties, new political spaces, and the questioning of the use of violence by sectors inside the main armed actor, ETA (Letamendia, 1994b: 35; Ibarra, 1987: 104). This aperture of the political opportunity structure gave way to new forms of action for peace networks and, more importantly, gave

11. Elements that define Gesto por la Paz: http://www.gesto.org/definicion.htm (accessed 20/02/2012) 
some sectors inside these networks the possibility of using the public space to reject violence.

The opening of the political opportunity structure did not only bring new opportunities but also created some grievances, such as the unsatisfactory response of the new democratic political parties. However, the new scenario was enough to nest the process that made peacesubmerged networks evolve to a new social movement (Kriesi, 2007; Tarrow, 1998; Tilly, 1978).

This is the environment where peace collective identity was negotiated. The process of collective identity inside the Basque peace movement is based on one basic principle: the total rejection of the use of violence as a political tool. This principle is derived from the processes previously explained and was created to differentiate a new way of doing politics. Therefore, it is intrinsically tied to the traditions within Basque politics. With a national identity group that sees violence as a valid tool, the Basque peace movement makes the opposite stand. That element relates the Basque peace movement organizations with the rest of society as a degree of distinction; the Basque peace movement is created in opposition to the political identity dynamics that were in place during the Dictatorship (Melucci, 1996: 73). The Basque peace action frame is tied to this collective identity factor, so the groups that share the same identity trait will find it easier to adopt the Basque peace action frame than other frames because, as Melucci states, it will be recognized and assumed as valid, while other identity groups will negotiate its status (Melucci, 1996: 73). This will be an exercise of recognition that will establish the Basque peace movement inside the different networks of relations in the Basque social environment (Hunt \& Benford, 1994: 489). There are subtle differences at the organizational level. Both organizations, Lokarri and Gesto por la Paz share the same fundamental pacifist trait, but the social nature of Gesto por la Paz makes the inclusion of national issues very difficult. In contrast, the organizational model defended by Lokarri, more functional and politically effective created to defend a political solution, makes possible the inclusion of national elements in their identity (Funes, 1998b: 501). Other differences come from their activism. In 
Gesto por la Paz a person becomes a member once they take part in a Gesto, while in Lokarri the same person has to participate in a campaign to collect signatures. These differences will be continuously in tension and negotiation, enriching the two organizations and their perspectives (Melucci, 1996: 76).

\section{FRAME EFFECTS OF THE BASQUE PEACE MOVEMENT. HOW DO THEY CHANGE SOCIETY?}

The Basque peace action frame has had a substantial impact in Basque society, changing the way violence is perceived. This change can be observed in all levels of Basque social network, but it is more significant if explored amongst social networks related to the conflict. Of these networks there are two that are particularly important for this analysis: the nationalist left, and the victims of terrorism networks. Both networks have been affected, and the ways they expressed themselves about violence changed by the impact of the Basque peace action frame. The nationalist left has found a way out of the spiral of violence, giving it different tools to offer its members with a comprehensive identity process without betraying its past. The victims of terrorism network reacted differently. It comes from a strong sense of injustice, and peace mobilization gave it a tool to express their injustice. As a consequence, they radicalized their discourse, not having any trait of pacifism in it. These changes, intended and unintended, came through sympathetic identity links, with Lokarri being the main communicator with the nationalist left, and Gesto por la Paz with the victims of terrorism.

The nationalist left does not share the same vision of the conflict as the Basque peace movement organizations. For the network, the conflict is a historical struggle for the rights of the Basque people. These rights are national rights that have been negated by the Spanish state, which ultimately bears sole responsibility for the current situation. ETA is just a consequence of the repressive action that comes from the 
Spanish state. That repression has been particularly hard during the Dictatorship and, for some sectors of the nationalist left that did not change with democracy. To solve the conflict, it is imperative for the Spanish state to recognize the rights of the Basque people, end the repression and let the Basque people decide their own future without external influences (Ibarra, 2005; Letamendia, 1994a; Zirakzadeh, 1991).

The Basque peace movement organizations have affected this network using an action-reaction dynamic. It has a more negative opinion of Gesto por la Paz and Lokarri. Regarding the latter, the feeling inside the organization is that they are well funded and do not follow the right objectives. Concerning Gesto por la Paz they feel that the organization only focuses on one side of the conflict, and during the 90s, they develop a confrontational strategy against the Gestos (Funes, 1998a).

That does not mean that the relationship between the Basque peace movement organizations and the nationalist left is completely negative. Both Lokarri, in its various documents devoted to describing the social situation ${ }^{12}$, and Gesto por la Paz ${ }^{13}$ supported different initiatives to ban torture and to acknowledge the rights of the prisoner's family members. The relationship with Lokarri is more interesting for this paper. The origins of Lokarri and its political proposal make the organization closer to the nationalist left network. Maria Jesus Funes, for example, asserts that Elkarri was a response from the nationalist left networks to the Basque peace movement (Funes, 1998a: 47; 1998b: 502). Part of the social base that formed Elkarri had a dualistic membership in the nationalist left and pacifist networks, but that does not mean that Elkarri was a nationalist project. This is the consequence of the homogenous exterior image of the nationalist left. Elkarri was created as a consequence of the political situation and the evolution of the Basque peace movement. The people that created

12. http://lokarri.org/index.php/es/observatorio-social (accessed 20/02/2012)

13. http://gesto.org/delitosterrorismo1.htm (accessed 20/02/2012). Gesto por la Paz document advocating for a fair treatment of ETA prisoners. And http://gesto.org/prensapdf/o8-01-08\%20NP\%20torturas\%20_1_.pdf (accessed 20/02/2012), denouncing a case of possible tortures. 
Elkarri shared similar identity trends as the people involved in the nationalist left, but were not part of it. This issue makes Lokarri, as the most direct expression of Elkarri, better accepted inside the network. Those channels of acceptance work in two ways, as explained, Lokarri is better accepted and the demands from the network are easily included in Lokarri's ethos. This issue makes easier to include a negotiation proposal inside the nationalist left discourse.

In conclusion, the impact of the Basque peace movement organizations on the nationalist left organizations analyzed in this research is subtle. This is because the identity trend is different as the nationalist left identity clashes if the issue of violence is raised. The acceptance of the use of violence by the nationalist left during the Dictatorship is what made the peace networks assume their identity trait rejecting violence. There are no open feedback channels and the changes are based in an action-reaction model. The exception is Lokarri. The shared past with the nationalist left gives it a more positive view inside the network. It is important to note the difficulties of the nationalist left to react to changes in the Political Opportunity Structure. This makes the Basque peace movement organizations use frame transformation processes to get inside those organizations. Finally, the analysis of the nationalist left gives the most important fact about Basque social interaction: the sharing of a collective identity, which is key to understanding the channels of influence.

The victims of terrorism vision of the conflict are the total opposite of the vision of the nationalist left. The only culprit of the political violence is ETA and the organizations that surround it. The victims of terrorism network have a narrow vision of the enemy and assume a bivalent view in which people are for ETA or against ETA. If the rejection of ETA is ambiguous, it is assumed that ETA is supported. The only possible solution for the conflict is the total dissolution of ETA and the penal punishment of any ETA member.

The most interesting conclusion of this analysis is that these organizations can articulate an aggressive message because of the spectacular success of the Basque peace movement during the end of the 9os. The efforts that Gesto por la Paz made to advocate for the victims of 
ETA and to break the social silence that surrounded the conflict made possible the space for the victims of terrorism network to send its message. An interesting consequence of this is the unusual need for social support that this network requires. Such support is not necessarily active and real per se, rather presents a perception of overall support for the messages it sends. Expressions like "the people are tired", or "the majority of society needs..." are common in the victims of terrorism discourse. Therefore, when the nationalist groups are mentioned, they are categorized as a small minority.

The victims of terrorism took the powerful message that was articulated by Gesto por la Paz and tailored it to the defense of the victims. This network has maintained this message in a very clear, simple way and have benefitted from the success of the Basque peace movement is a message that is very difficult to question. That has direct effect on the framework generation of the Basque peace movement organizations. It is very difficult to speak negatively of the victims of terrorism. It is difficult to question their role as political figures. The victims have a powerful role as pressure figures and their discourse is perceived as politically legitimate. Lokarri felt the need to put the rights of the victims up front in its political proposal. Gesto por la Paz concentrated in promoting the victims' rights during this research. On the other hand, the political component of the victims of terrorism does not enjoy such popular support. The sectarian vision promoted by Lokarri of the political approach from the victims of terrorism gave Lokarri a solid ground to affirm its political proposal.

In conclusion, the victims of terrorism network developed their collective identity based on the rejection of ETA violence and Basque nationalism. This gave them communication channels at the individual level with some Gesto por la Paz members, but none with Lokarri. The effects between the victims of terrorism network and the Basque peace movement organizations are based in an action-reaction dynamic more than a process of dialogue. This dynamic is centered in the political messages. The defense of victims of terrorism message is the most powerful tool that this network has, giving the Basque peace movement organizations a narrow margin of action about it. Gesto 
por la Paz had the defense of victims of terrorism always present, but for Lokarri it raises some questions. Inside the organization exists a feeling that the victims of terrorism are overestimated in the conflict, but the majority of Lokarri members are aware that raising those concerns in public can damage the political message Lokarri is sending.

\section{CONCLUSIONS}

The Basque peace movement organizations Lokarri and Gesto por la Paz emerged from submerged networks created during the Dictatorship. These networks have, as a central identity trait, the rejection of the use of violence to achieve political goals. These networks had very limited access to the public space because political protest was centered on Basque national claims. These claims were highly contentious and deeply associated with the use of political violence. The arrival of democracy to the Basque Country gave the opportunity to these peace networks to become a social movement for two reasons: first, the opening of new public spaces of protests, with the legalization of public protesting and the introduction of political pluralism, and; second, the questioning of the violence from some social sectors. This new environment allowed the perception that the public space was available for protesting. The Basque peace movement started to develop a new way of protesting. This new way had to fit two purposes, namely, to fit into the new political environment, and to confront the social groups that still defended the use of violence. This new kind of mobilization was based on the opposite ethos of the contentious nationalist mobilization. If the latter was violent and full of noise, the peace mobilization was peaceful and silent. This new way of mobilization succeeded in winning the public space and created the perception that new ways of political protest were possible. This new way of approaching politics, rejecting the use of violence, is the main contribution of the Basque peace movement to Basque society. Today, the use of violence is no longer seen as a plausible tool to achieve political means. The Basque peace movement organizations were able to create 
a frame that permeated most of the social layers that, now, prevents even the mere suggestion of using violence. The Basque peace movement organizations were able to detach themselves from nationalistic politics and propose a new way of approaching those politics. They did that cleverly using the social spaces and developing a specialized nature that helped them to work efficiently. To explore the Basque Peace Frame is to study that process where the rejection of violence impregnated Basque politics and Basque social life.

The awakening of that peace identity is crucial to understand the current political situation in the Basque Country. Gesto por la Paz and Lokarri have been able to arise issues that were not debatable twenty years ago. In this paper the two peace organisations have been presented, since they were created until now. They developed a Basque peace frame that successfully permeated the different levels of Basque society and finally made possible a peaceful conflict outcome. The future is new, with a path that the current generation have not seen before, but it is not too bold to assert that the peace organisations have created a guide that might help society to move forward and leave violence behind.

\section{BIBLIOGRAPHY}

AJangiz, R. (2002) Politica Militar y Movimientos Sociales: El fin de la conscripcion en Europa, Bilbao, Servicio Editorial de la UPV/ EHU.

- Alvarez-Junco, J. (1994) Social Movements in Modern Spain: From the Pre-Civil War Model to Contemporary NSMs. IN LARAÑA, E., JOHNSTON, H. \& GUSFIELD, J. R. (Eds.) New Social Movements. From Ideology to Identity. Philadelphia, Temple University Press.

Anton, E. (2009) Crossing the digital gap. Effects of new technologies of communication in social action. Remembering War, Genocide and Other Human Rights Violations: Oral History, New Media and the Arts Conference. Concordia University, Montreal, Canada. 
Anton, E. (2011) The Impact of Peace Movements on a Society Immersed in Conflict: An analysis of the framing processes of the Basque peace movement. Department of Peace Studies. Bradford, University of Bradford.

- Barcena, I., IbARra, P. \& Zubiaga, M. (1995) Nacionalismo y Ecologia. Conflicto e institucionalización en el movimiento ecologista vasco, Madrid, Libros de la Catarata.

- Barcena, I., Ibarra, P. \& Zubiaga, M. (1998) Movimientos sociales y democracia en Euskadi. Insumision y ecologismo. IN IBARRA, P. \& TEJERINA, B. (Eds.) Los Movimientos Sociales, transformaciones politicas y cambio cultural. Madrid, Trotta.

- Bartholomew, A. \& Mayer, M. (1992) "Nomads of the Present: Melucci's Contribution to 'New Social Movement' Theory”. Theory, Culture \& Society,(9) 141-159.

- Casquette, J. (1998) Política, Cultura y Movimientos Sociales, Bilbao, Bakeaz.

- CAsquette, J. (2003) From Imagination to Visualization: Protest Rituals in the Basque Country, Berlin, WZB.

- CAsquette, J. (2005) "Manifestaciones e identidad Colectiva”. Revista Internacional de Sociologia,(42) 101-25.

- CASquette, J. (2006) El poder de la calle. Ensayos sobre accion colectiva, Madrid, Centro de Estudios Politicos y Constitucionales.

Castells, M. (1998) Globalization, Identity and the Basque Question. IN DOUGLASS, W., ZULAIKA, J., WHITE, L. \& URZA, C. (Eds.) Basque Politics and Nationalism on the Eve of the Millenium. Reno, University of Nevada Press.

- De la PeÑa, A. \& IBARRA, P. (2004) De la confrontación militante a la cooperación pragmática. Nuevas formas de acción colectiva en Euskadi, Madrid, Libros de la Catarata.

- Diani, M. (1992) “The concept of social movement”. The Sociological Review,(38) 1-25.

- Dominguez, F. (2003) Las raices del miedo. Euskadi una sociedad atemorizada, Madrid, Aguilar.

- Funes, M. J. (1998a) La Salida del Silencio. Movilizaciones por la paz en Euskadi 1986-1998, Madrid, Akal. 
- Funes, M. J. (1998b) "Social Responses to Political Violence in the Basque Country. Peace movements and their audience". Journal of Conflict Resolution, 42,(4) 493-510.

- Gamson, W. A. (1992) Talking Politics, New York, Cambridge University Press.

- GERHARDS, J. \& Rucht, D. (1992) "Mesomobilization: organizing and framing in two protest campaigns in West Germany". American Journal of Sociology,(98) 555-595.

- Goffman, E. (1974) Frame Analysis, Cambridge, Harvard University Press.

- Hunt, S., Benford, R. D. \& Snow, D. A. (1994) Identity fields: framing processes and the social construction of movement identities. IN LARAÑA, E., JOHNSTON, H. \& GUSFIELD, J. (Eds.) New Social Movements: From Ideology to Identity. Philadelphia, Temple University Press.

- Hunt, S. A. \& Benford, R. D. (1994) "Identity Talk in the Peace and Justice Movement”. Journal of Contemporary Ethnography, 22,(4) 488-517.

- IBARRA, P. (1987) La Evolución estratégica de E.T.A., San Sebastian, Kriselu.

- IbarRa, P. (2005) Nacionalismo. Razón y Pasión, Madrid, Ariel.

- KRIESI, H. (2007) Political Context and Opportunity. IN SNOW, D. A., SOULE, S. A. \& KRIESI, H. (Eds.) Blackwell Companion to Social Movem

- Letamendia, F. (1994a) Historia del Nacionalismo Vasco y de E.T.A. Vol 1. E.T.A en el Franquismo, San Sebastian, R\&B Editores. LETAMEndia, F. (1994b) Historia del Nacionalismo Vasco y de E.T.A. Vol 2. E.T.A. en la Transicion, San Sebastian, R\&B Editores. LetaMendia, F. (1994c) Historia del Nacionalismo Vasco y de E.T.A. Vol 3. E.T.A. y el Gobierno del PSOE, San Sebastian, R\&B Editores.

Melucci, A. (1988) Getting Involved: Identity and Mobilization in Social Movements. IN KLANDERMANS, B., KRIESI, H. \& TARROW, S. (Eds.) From Structure to Action: Comparing Social Movement Research Across Cultures. Greenwich, JAI Press. 
Melucci, A. (1989) Nomads of the Present, London, Hutchinson Radius.

- Melucci, A. (1996) Challenging Codes. Collective Action in the information age, Cambridge, Cambridge University Press.

- Muro, D. (2008) Ethnicity and Violence: The Case of Radical Basque Nationalism, London, Routledge.

- Overy, B. (1982) How effective are peace movements?, London, Harvest House.

- Perez-Agote, A. (1998) The Future of Basque Identity. IN DOUGLASS, W., ZULAIKA, J., WHITE, L. \& URZA, C. (Eds.) Basque Politics and Nationalism on the Eve of the Millenium. Reno, University of Nevada Press.

- Perez-Agote, A. (2008) Las Raices Sociales del Nacionalismo Vasco, Madrid, CIS.

- Snow, D. A. \& Benford, R. D. (1988) Ideology, frame resonance and participant mobilization. IN KLANDERMANS, B., KRIESI, H. \& TARROW, S. (Eds.) From Structure to Action: Comparing Social Movement Research Across Cultures. Greenwich, JAI Press.

- Snow, D. A. \& Benford, R. D. (2000) "Framing Processes and Social Movements: An Overview and Assessment”. Annual Review of Sociology,(26) 611 - 639.

- SNow, D. A., Rochford, B. E., Worden, S. K. \& Benford, R. D. (1986) "Frame Alignment Processes, Micromobilization, and Movement Participation". American Sociological Review, 51, (August) 464481.

- TARrow, S. (1998) Power in Movement. Social Movements and contentious politics, Cambridge, Cambridge University Press.

- TeJERInA, B. (2001) "Protest Cycle, political violence and social movements in the Basque Country". Nations and Nationalism, 7,(1) 39-57.

- Tilly, C. (1978) From Mobilization to Revolution, New York, McGraw-Hill.

- Tilly, C. (1984) Social Movements and National Politics. IN BRIGHT, C. \& HARDING, S. (Eds.) Statemaking and Social Movements. Ann Arbor, Michigan, University of MIchigan Press. 
- Wieviorka, M. (1993) The Making of Terrorism, Chicago, University of Chicago Press.

- Zirakzadeh, C. E. (1991) A Rebellious People. Basques, Protests, and Politics, Reno, University of Nevada Press. 


\section{ICIP WORKING PAPERS SUBMISSION GUIDELINES:}

\section{International Catalan Institute for Peace (ICIP)}

- The principle purpose of the ICIP is to promote a culture of peace in Catalonia as well as throughout the world, to endorse peaceful solutions and conflict resolutions and to endow Catalonia with an active role as an agent of peace and peace research. The ICIP, seeking consistency between ends and means, is governed by the principles of promoting peace, democracy, justice, equality and equity in relationships between individuals, peoples, cultures, nations and states. It holds the aim of working for human security, disarmament, the prevention and peaceful resolution of conflicts and social tensions, and strengthening the roots of peace and coexistence, peace building and advocacy of human rights.

\section{Objectives of the Publication}

- The ICIP wants to create an open forum on topics related to peace, conflict and security. It aims to open up debate and discussion on both theoretical and contemporary issues associated with the pursuit and maintenance of peace in our world. It strives to connect an eclectic group of voices including career academics, $\mathrm{PhD}$ students, NGO representatives, institutional representatives, and field workers and field writers to celebrate ground-breaking and constructive approaches to peace and conflict resolution.

\section{Scope of the Publication (List of Themes)}

- The ICIP is interested in works related to peace, conflict and security research. It aims to provide an innovative and pluralist insight on topics of methodology of peace research, the history and development of peace research, peace education, 
peace-keeping and peace-creating, conflict resolution, human security, human rights, global security, environmental security, development studies related to peace and security, international law related to peace, democracy, justice and equality, disarmament, gender, identity and ethics related to peace, science and technology associated with peace and security.

\section{Audience:}

- The ICP aims to provide accessible, valuable and well-researched material for all those interested in the promotion of peace. Our audience includes fellow academics and researchers, student of peace ands security, field workers, institutional and governmental representatives as well as the general public.

\section{The review process}

- Peer reviewed. Submissions should be sent directly to the series editor (recerca.icip@gencat.cat), who will check whether the paper meets the formal and general criteria for a working paper and will commission a review.

The review procedure is double-blind. The series editor will choose two anonymous reviewers, generally from the Editorial Board, but may also commission an external review from outside the ICIP.

- Reviewers are asked to write a review within a month after having received the paper. Reviews should clearly indicate one of four options: (1) accept without changes; (2) accept with minor changes; (3) allow for resubmission after major changes (4) reject. Options 2 to 4 require some detailed comments. If a paper is accepted (option 1 or 2), reviewers are kindly asked to help authors correct minor linguistic or other errors by making notes in the manuscript. If they use the track changes function for this purpose they should make sure that their comments are anonymized. 


\section{Who may submit working papers?}

- The main criterion for the submission of Working Papers is whether this text could be submitted to a good academic journal.

- ICIP staff and other fellows and visitors affiliated with the ICIP are expected to submit a working paper related to their research while at the ICIP.

\section{Submission System}

- All submissions can be made to the ICIP e-mail address: recerca.icip@gencat.cat with Working Papers - submission in the subject line.

\section{Author Biographical Statement}

- Authors must all provide a short biographical note including full name, affiliation, e-mail address, other contact information if necessary and a brief professional history. This information should be provided on a separate sheet with the title. All other personal references should be removed from the submission to ensure anonymity.

\section{Abstract}

- All papers must include English language abstracts (150 words max.)

\section{Keywords}

n A list of four to six keywords is also required.

\section{Language and Style}

- Authors may submit in Catalan, Spanish or English. The submission must be clearly written and easy to follow with headings demarcating the beginning of each section. Submission must in be Arial 11, double spaced and pages must be numbered. 
- Papers should not be longer than 15.000 words (incl. footnotes and references). Longer papers may be returned with a request to shorten them. Papers that require more extensive presentation of data may add these in an appendix that will count separately. Appendices should, however, present data in a reader-friendly and condensed format.

- Papers that will require extensive linguistic editing will not be accepted for review. Minor linguistic corrections (as well as required revisions) suggested by the reviewer must be implemented by the author before the final editing of the paper.

\section{Footnotes}

- Footnotes may be used to provide the reader with substantive information related to the topic of the paper. Footnotes will be part of the word count.

\section{References}

- The Harvard author-date system. In this system, sources are briefly cited in the text, usually in parentheses, by author's last name and date of publication. The short citations are amplified in a list of references in alphabetical list, where full bibliographic information is provided. Bibliographic references must follow The Chicago Manual of Style ( $15^{\text {th }}$ edition). See a Chicago-Style citation quick guide at:

http://www.chicagomanualofstyle.org/tools_citationguide.html Citation generators:

http://www.workscited4u.com/

http://citationmachine.net/ 


\section{ICIP WORKING PAPERS}

$$
2011 / 7
$$

Segregation and the onset

of civil war

by Lesley-Ann Daniels

(available in Catalan and English)

\section{$2011 / 6$}

Mechanisms of Neo-colonialism.

Current French and British

influence in Cameroon and Ghana

by Diana Haag

(available in Catalan and English)

\section{$2011 / 5$}

Una anàlisi comparativa de la despesa militar espanyola en el molt llarg termini (1850-2009) by Alonso Herranz, Oriol Sabaté and Gregori Galofré-Vilà

(available in Catalan and English)

\section{$2011 / 4$}

El foro social mundial y los movimientos antisistémicos by Jordi Calvo (available in Catalan and English)

\section{$2011 / 3$}

Cultural Relativism in the Universal Periodic Review of the Human Rights Council by Roger Llovet Blackburn (available in Catalan and English)

\section{$2011 / 2$}

Nuevas tendencias en la construcción de la paz.

Otra forma de innovación Social by Paul Ríos and Gorka Espiau (available in Spanish and English)

\section{$2011 / 1$}

La lucha contra la impunidad de los crímenes internacionales en España: de la persecución a Pinochet a la inculpación del juez Garzón by Claudia Jiménez Cortés (available in Spanish and English)

\section{$2010 / 9$}

The Security Council and the Legitimacy of the Use of Force: Legal, Normative, and Social Aspects by Matilde Pérez Herranz (available in Spanish and English)

\section{$2010 / 8$}

Conflict, Peace and Security in Africa: an Assessment and New Questions After 50 Years of African Independence by Rafael Grasa and Oscar Mateos (available in Catalan and English)

\section{$2010 / 7$}

La OEA y la promoción de la democracia en las Américas: un objetivo en construcción by Neus Ramis (available in Spanish and English) 

INTERNATIONAL

CATALAN

INSTITUTE

\section{FOR PEACE}

GRAN VIA DE LES CORTS CATALANES 658, BAIX

08010 BARCELONA (SPAIN)

T. +3493554 4270 | F. +34935544280

ICIP@GENCAT.CAT | WWW.ICIP.CAT 